\title{
PENINGKATKAN HASIL BELAJAR MATEMATIKA \\ MELALUI MODEL PEMBELAJARAN KOOPERATIF TIPE MAKE A MATCH BAGI SISWA KELAS VIIIG SMP NEGERI 2 TUNTANG KABUPATEN SEMARANG TAHUN AJARAN 2015/2016
}

\author{
Tri Muah \\ Trimuah150767@gmail.com \\ SMP Negeri 2 Tuntang Kabupaten Semarang
}

\begin{abstract}
ABSTRAK
Penelitian tindakan kelas ini bertujuan untuk meningkatkan hasil belajar siswa kelas VIIIG SMP Negeri 2 Tuntang dengan model Pembelajaran Kooperatif tipe Make a match pada materi persamaan garis lurus. Model Pembelajaran Kooperatif tipe Make a match merupakan salah satu model Pembelajaran Kooperatif dimana siswa bekerja sama mencari pasangan masing-masing. Penelitian ini terdiri dari dua siklus. Tiap siklus terdiri dari empat tahapan yaitu: perencanaan, pelaksanaan, pengamatan, dan refleksi. Pengumpulan data menggunakan catatan lapangan, observasi, tes dan wawancara. Alat pengumpulan data adalah lembar observasi, pedoman wawancara, dan butir soal. Analisis data dalam penelitian tindakan kelas ini menggunakan teknik analisis deskriptif. Hasil yang didapat dalam penelitian ini: siklus 1 dilakukan selama 2 pertemuan dengan hasil persentase siswa yang nilainya di atas KKM sebanyak 53,33\%. Siklus 2 dilakukan selama 2 pertemuan dengan hasil persentase siswa yang nilainya di atas KKM sebanyak 76.67\%. Berdasarkan hasil penelitian didapatkan bahwa Model Pembelajaran Kooperatif tipe Make A Match dapat meningkatkan hasil belajar siswa kelas $8 \mathrm{G}$ SMP Negeri 2 Tuntang.
\end{abstract}

Kata kunci: pembelajaran kooperatif Make a Match, hasil belajar

\section{PENDAHULUAN}

Mata pelajaran matematika adalah salah satu mata pelajaran yang memberikan kontribusi positif untuk tercapainya masyarakat yang cerdas dan bermartabat melalui sikap kritis dan berfikir logis. Matematika sebagai salah satu ilmu dasar yang penting diajarkan supaya siswa mampu berhitung, berpikir kritis, kreatif, teliti dan logis. Kurangnya ketahanan pribadi dalam belajar matematika dapat berpengaruh besar terhadap gairah belajar matematika. Jika hal ini dibiarkan maka siswa akan semakin tidak menyenangi matematika bahkan pada taraf tertentu akan bersikap anti pati pada pelajaran matematika. Hal ini berakibat pada prestasi belajar matematika akan semakin rendah.
Pembelajaran matematika di SMP N 2 Tuntang khususnya siswa kelas 8 tergolong rendah. Rendahnya hasil belajar matematika di kelas VIIIG SMP Negeri 2 Tuntang, nampak pada rata-rata prestasi belajar siswa masih di bawah KKM (70). Berdasarkan tes materi menggambar persamaan garis lurus bahwa dari 30 siswa kelas VIIIG, ada 3 siswa (10\%) mendapatkan nilai di atas KKM sedangkan 27 siswa (90\%) belum mencapai KKM. selanjutnya hasil rata-rata kelas diperoleh sebesar 53,4.

Hasil pengamatan proses pembelajaran matematika di SMP Negeri 2 Tuntang menunjukkan bahwa pembelajaran masih berpusat pada guru. Pada saat kegiatan belajar di kelas sebagian besar siswa cenderung pasif, 
siswa juga beranggapan bahwa matematika itu pelajaran yang menakutkan dan membosankan. Berdasarkan masalah tersebut, perlu dilakukan perbaikan yang terkait pada proses pembelajaran. Upaya yang dilakukan dalam rangka perbaikan ialah melalui penerapan model pembelajaran kooperatif tipe Make a Match dalam materi persamaan garis lurus yang akan diajarkan.

\section{KAJIAN PUSTAKA MATEMATIKA}

Wahyudi (2012:10) menjelaskan bahwa matematika berkenaan dengan ide (gagasangagasan), aturan-aturan, hubungan-hubungan, yang diatur secara logis sehingga matematika berkaitan dengan konsep-konsep abstrak. Selanjutnya, Heruman (2007:27) mengemukakan matematika sebagai ilmu pengetahuan yang mempelajari struktur yang abstrak dan pola hubungan yang ada di dalamnya. Hal ini berarti belajar matematika pada hakekatnya adalah belajar konsep, struktur konsep dan mencari hubungan antar konsep dan strukturnya.

Menurut lampiran Permendiknas No. 22 Tahun 2006 (Depdiknas, 2006) matematika merupakan ilmu universal yang mendasari perkembangan teknologi modern, mempunyai peran penting dalam berbagai disiplin dan memajukan daya pikir manusia. Perkembangan pesat teknologi informasi dan komunikasi dewasa ini dilandasi oleh perkembangan matematika di bidang teori bilangan, aljabar, analisis, teori peluang dan matematika diskrit. Mata pelajaran matematika perlu diberikan kepada semua peserta didik untuk membekali peserta didik dengan kemampuan berpikir logis, analitis, sistematis, kritis, dan kreatif, serta kemampuan bekerjasama. Kemampuan itu diperlukan agar siswa memiliki kemampuan memperoleh, mengelola, dan memanfaatkan informasi untuk bertahan hidup pada keadaan yang selalu berubah, tidak pasti, dan kompetitif.

Pembelajaran matematika hendaknya dimulai dengan pengenalan masalah yang sesuai dengan situasi (contextual problem). Dengan mengajukan masalah kontekstual, peserta didik secara bertahap dibimbing untuk menguasai konsep matematika. Untuk meningkatkan keefektifan pembelajaran, sekolah diharapkan menggunakan teknologi informasi dan komunikasi seperti komputer, alat peraga, atau media lainnya.

Berdasarkan pendapat di atas dapat disimpulkan bahwa matematika ialah suatu pelajaran yang tersusun secara beraturan, logis, berjenjang dari yang paling mudah hingga ke paling rumit. Sedangkan pembelajaran matematika hakikatnya adalah proses dirancang dengan tujuan untuk menciptakan suasana lingkungan yang memungkinkan siswa melaksanakan kegiatan belajar matematika yang mampu menanamkan konsep matematika secara jelas, tepat dan akurat kepada siswa sesuai dengan jenjang kelasnya.

Berpijak pada hakikat dan karakterisik pembelajaran matematika seperti telah diuraikan diatas, maka guru mata pelajaran matematika perlu mempertimbangkan rancangan pembelajaran yang memungkinkan siswa untuk berpikir logis, analitis, sistematis, kritis, dan kreatif, serta kemampuan bekerjasama melalui model pembelajaran kooperatif make a match.

Uraian secara medalam atau mendetail tentang model pembelajaran kooperatif make a match dan hasil belajar pada bagian tersendiri

\section{Model Pembelajaran Kooperatif (Cooperative Learning)}

Pengertian Pembelajaran Kooperatif menurut Isjoni (2011) adalah sistem pembelajaran yang memberikan kesempatan kepada peserta didik untuk bekerjasama 
dengan peserta didik lain dalam tugas-tugas yang terstruktur selanjutnya guru bertindak sebagai fasilitator. Belajar kooperatif menurut Anitah (2008) adalah pembelajaran yang menggunakan kelompok kecil sehingga siswa bekerja sama untuk memaksimalkan kegiatan belajarnya sendiri dan juga anggota yang lain. Dari dua definisi tentang pembelajaran kooperatif dapat disimpulkan sebagai kegiatan pembelajaran dengan cara berkelompok untuk bekerja sama menyelesaikan persoalan.

Konsep pembelajaran kooperatif pada intinya menempatkan pengetahuan yang dimiliki siswa yaitu hasil dari aktivitas yang dilakukan, bukan pengajaran yang diterima secara pasif (Isjoni, 2010). Hasil pembelajaran kooperatif dapat bermanfaat bagi siswa yang memiliki prestasi rendah namun berusaha memperoleh pengetahuan dari pada kelompok siswa yang prestasinya tinggi yang tidak berpikir untuk memperolehnya. Siswa yang lemah belajar dengan konsep yangmenantang melalui interaksi dengan siswa yang pintar dengan mendorong keberhasilan mereka serta menimbulkan perjuangan di dalam kelas. Siswa yang pintar dalam belajar kelompok dapat memperluas pemahaman mereka karena menjelaskan konsep-konsep pada siswa yang lain (Isjoni, 2010).

\section{Model Pembelajaran Kooperatif Tipe Make a Match}

Model pembelajaran make a match atau mencari pasangan menurut Kunandar (2008) adalah model pembelajaran kooperatif dengan cara mencari pasangan soal atau jawaban yang tepat dan siswa yang sudah menemukan pasangannya sebelum batas waktu akan diberi poin. Model pembelajaran kooperatif tipe make a match ini dikembangkan oleh Lorna Curran (1994). Salah satu keunggulan teknik ini adalah peserta didik mencari pasangan sambil belajar mengenai suatu konsep atau topik dalam suasana yang menyenangkan. Teknik ini bisa digunakan dalam semua mata pelajaran dan untuk semua tingkatan usia anak didik.

Kunandar (2008) menyebutkan langkahlangkah model pembelajaran kooperatif tipe make a match sebagai berikut: (1) guru menyiapkan kartu yang berisi beberapa konsep atau topik yang cocok untuk sesi review, bagian depan berisi soal, sedangkan bagian belakang berisi jawaban; (2) setiap siswa mendapat satu kartu; tiap siswa memikirkan jawaban dan soal dari kartu yang dipegang; (3) setiap siswa mencari pasangan yang mempunyai kartu yang cocok dengan kartunya; (4) setiap siswa yang dapat mencocokkan kartunya sebelum batas waktu, maka akan diberi hadiah atau poin; (4) setelah satu babak, kartu dikocok lagi agar tiap siswa mendapat kartu yang berbeda dari sebelumnya.

Kelebihan dari model pembelajaran kooperatif tipe make a match yaitu, dapat meningkatkan aktivitas belajar siswa, baik secara kognitif maupun fisik; ada unsur permainan, metode ini menyenangkan; meningkatkan pemahaman siswa terhadap materi yang dipelajari; dapat meningkatkan motivasi belajar siswa; efektif sebagai sarana melatih keberanian siswa untuk tampil presentasi; efektif melatih kedisiplinan siswa menghargai waktu untuk belajar.

\section{Hasil Belajar}

Poerwadarminto (2003:348) mengatakan bahwa hasil belajar merupakan hasil yang dicapai setelah seseorang mengadakan suatu kegiatan belajar yang terbentuk dalam bentuk suatu nilai hasil belajar yang diberikan guru. selanjutnya, Tu'u(2004: 75) menyatakan bahwa hasil belajar dibuktikan dan ditunjukkan melalui nilai, atau angka nilai dari hasil evaluasi yang dilakukan oleh guru terhadap tugas siswa dan 
ulangan-ulangan atau ujian yang ditempuhnya. Hasil belajar menurutAnni (2004:4) merupakan perubahan perilaku yang diperoleh pembelajar setelah mengalami aktivitas belajar, sedangkan hasil belajar menurut Sudjana (1990:22) adalah kemampuan yang dimiliki siswa setelah ia menerima pengalaman belajarnya. Berdasarkan pengertian di atas dapat disimpulkan bahwa hasil belajar adalah hasil yang dicapai oleh siswa setelah siswa melakukan kegiatan belajar. Hasil belajar ini berupa nilai yang diberikan oleh guru sebagai bentuk dari pengalaman belajar.

Gagne seperti dikutip oleh Kunandar (2008) menyebutkan bahwa ada lima kategori hasil belajar, yakni: informasi verbal, kecakapan intelektul, strategi kognitif, sikap dan keterampilan. Sementara itu Bloom mengungkapkan tiga tujuan pengajaran yang merupakan kemampuan seseorang yang harus dicapai dan merupakan hasil belajar yaitu: kognitif, afektif, dan psikomotorik (Sudjana, 1990:22).

Penelitian ini mengacu pada hasil belajar menurut Kunandar (2008) dimana hasil belajar yang dimiliki siswa setelah ia menerima pembelajaran dari guru. Pemahaman yang dimiliki siswa dapat mengontrol nilai yang akan dicapai siswa, sehingga setiap siswa memiliki kepuasan terhadap kemampuan yang dimiliki dan nilai atau hasil belajar yang didapatnya.

\section{METODE PENELITIAN}

Penelitian dilaksanakan pada bulan Oktober sampai dengan November pada semester gasal tahun ajaran 2015/2016 pada materi persamaan garis lurus. Lokasi penelitian dilakukan di SMP Negeri 2 Tuntang yang terletak di Jln. Mertokusumo, Ds. Candirejo, Kec. Tuntang, Kab. Semarang. Pemilihan tempat didasarkan pada pertimbangan bahwa di kelas VIIIG SMP Negeri 2 Tuntang masih mengalami masalah dalam hasil belajar siswa pada mata pelajaran matematika yang masih rendah. Subyek penelitian adalah siswa kelas VIIIG yang berjumlah 30 siswa.

Sumber data dalam penelitian ini ialah diperoleh dari wawancara, observasi, dan nilai tes formatif siswa. Teknik pengumpulan data menggunakan tes dan catatan harian.

\section{Hasil dan Pembahasan}

Penelitian tindakan kelas dilakukan di SMP Negeri 2 Tuntang yaitu kelas VIIIG berjumlah 30 siswa. Berdasarkan hasil observasi dan wawancara sebelum dilakukan penelitian, hasil belajar siswa kelas VIIIG tergolong rendah yaitu dari 30 siswa, ada 27 siswa (10\%) belum tuntas.

Selanjutnya dilakukan perbaikan melalui 2 siklus, siklus 1 dilaksanakan dalam dua pertemuan. Pada pertemuan 1 guru menerapkan model pembelajaran kooperatif tipe make a match yaitu dengan membagikan kartu-kartu soal kepada seluruh siswa, bagian depan adalah soal dan bagian belakang adalah jawaban milik teman. Siswa mengerjakan soal-soal di dalam kartu sampai batas waktu yang ditentukan, kemudian mencari pasangan jawaban dari kartu yang didapat. Hal ini bertujuan agar siswa mau berperan aktif dalam setiap pembelajaran, tidak pasif hanya duduk mendengarkan penjelasan guru. Hasil pengamatan setelah dilakukan penerapan make a match pada pertemuan 1 , siswa sudah mulai aktif mengerjakan soal yang diberikan oleh guru, namun masih ada siswa yang bingung dengan langkah pembelajaran dengan make a math karena baru pertama kali diterapkan. Pertemuan 2, siswa sudah terbiasa dengan model pembelajaran kooperatif tipe make a match. Terlihat ketika proses pengerjaan soal, keseluruhan siswa sudah memiliki kesadaran akan tugas yang diberikan. Akhir siklus I, yaitu setelah pertemuan 1 dan 2, dilakukan tes siklus I (post test 1) untuk mengukur tingkat pemahaman siswa. 
Siklus II dilaksanakan dalam dua pertemuan, pertemuan 1 melanjutkan materi siklus I, menggunakan model pembelajaran koperatif make a match. Setiap siswa diberikan sebuah kartu soal, bagian depan adalah soal dan bagian belakang adalah jawaban milik teman. Siswa mengerjakan soal di dalam kartu sampai batas waktu yang ditentukan, kemudian mencari pasangan jawaban dari kartu yang didapat. Pertemuan 2 , pembelajaran diawali dengan penyampaian tujuan pembelajaran yang ingin dicapai, guru menjelaskan materi dengan model pembelajarannya make a match. Hasil pengamatan siklus II, siswa sangat antusias dan berperan aktif dalam seluruh proses pembelajaran, terlihat bahwa siswa asyik dalam mengerjakan soal dan mencari pasangan kartu. Siswa yang sebelumnya pasif mau berinteraksi dengan guru, bertanya jika ada materi yang belum paham. Akhir siklus II, yaitu setelah pertemuan 1 dan 2, dilakukan tes siklus II (post test 2) untuk mengukur tingkat pemahaman siswa. Tabel 1 berikut adalah hasil belajar siswa SMP Negeri 2 Tuntang pada setiap siklus.
Berdasarkan Tabel 1 dan Gambar 1, hasil belajar kondisi awal sampai siklus II terdapat selisih tingkat persentase dari indikator keberhasilan. Ketuntasan pada kondisi awal mengalami peningkatan pada siklus I yaitu dari $10 \%$ menjadi $53,33 \%$ dengan selisih $43.33 \%$. Peningkatan juga terjadi pada siklus I ke siklus II yaitu dari $53.33 \%$ menjadi $76.67 \%$ dengan selisih $23,34 \%$. Dari data diatas dapat disimpulkan bahwa hasil belajar siswa sudah mencapai indikator keberhasilan yang telah ditetapkan yaitu $70 \%$ siswa tuntas.

\section{SIMPULAN DAN SARAN}

\section{Simpulan}

Berdasarkan hasil penelitian yang dilaksanakan melalui penelitian tindakan kelas melalui penerapan model cooperetive learning tipe make a match dapat meningkatkan hasil belajar siswa kelas VIIIG SMP Negeri 2 Tuntang. Peningkatan hasil belajar ini dapat dilihat dari persentase tingkat kelulusan siswa pada pra siklus, siklus I dan siklus II. Persentase tingkat kelulusan pada kondisi awal adalah $10 \%$, pada siklus I adalah $53.33 \%$ dan pada

Tabel 1 Hasil Tiap Siklus

\begin{tabular}{ccccccc}
\hline \multirow{2}{*}{ KONDISI } & \multicolumn{2}{c}{ KONDISI AWAL } & \multicolumn{2}{c}{ SIKLUS I } & \multicolumn{2}{c}{ SIKLUS II } \\
\cline { 2 - 7 } & Jumlah & Persentase & Jumlah & Persentase & Jumlah & Prosentase \\
\hline Tuntas & 3 siswa & $10 \%$ & 16 siswa & $53,33 \%$ & 23 siswa & $76.67 \%$ \\
Tidak & 27 siswa & $90 \%$ & 14 siswa & $46,67 \%$ & 7 siswa & $23.33 \%$ \\
Tuntas & & & & & & \\
\hline JUMLAH & 30 siswa & $100 \%$ & 30 siswa & $100 \%$ & 30 siswa & $100 \%$ \\
\hline
\end{tabular}

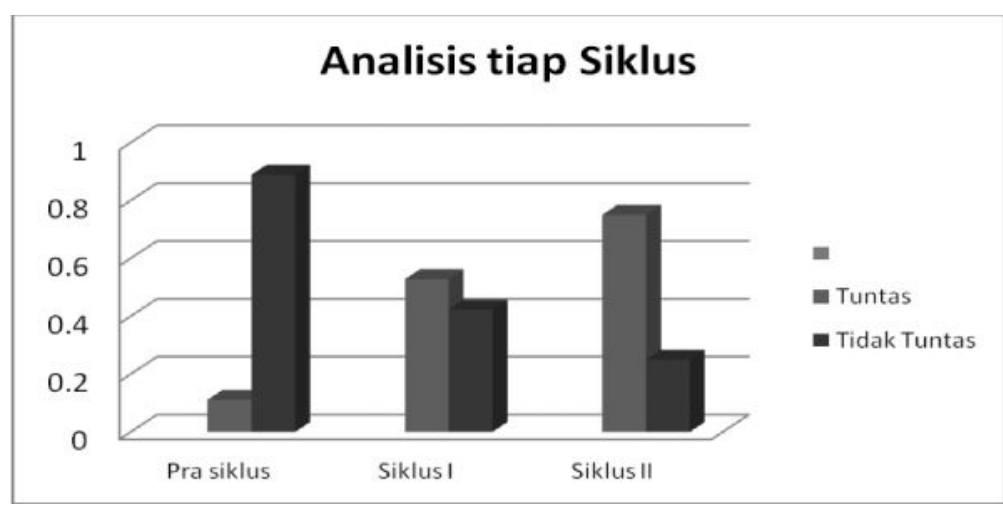

Gambar 1. Persentase ketuntasan hasil tiap siklus 
siklus II adalah 76.67\%. Jadi penerapan model pembelajaran kooperatif tipe make a match dapat meningkatkan hasil belajar siswa pada materi garis singgung di kelas 8 G SMP Negeri 2 Tuntang.

\section{Saran}

Berdasarkan hasil refleksi pada siklus I dan II dengan penerapan model cooperetive tipe make a match kelas 8G SMP Negeri 2 Tuntang pada materi persamaan garis lurus maka disampaikan saran kepada sekolah, guru, dan peneliti lain. Adapun saran tersebut adalah:

1. Hendaknya guru memperhatikan setiap siswa yang tidak hadir saat pembelajaran berlangsung, karena akan ada kendala dalam pembelajaran menggunakan make a match .

2. Sebelum melakukan penelitian hendaknya guru memperkaya pemahaman tentang model cooperative learning tipe make a match.

3. Pihak guru disarankan untuk menjadikan model cooperative learning tipe make a match sebagai suatu referensi dalam pembelajaran.

\section{DAFTAR PUSTAKA}

Anni. 2004. Psikologi Belajar. Semarang: UPT MKK: Universitas Semarang.

Heruman. 2007. Model pembelajaran matematika di Sekolah Dasar. Bandung: PT Remaja Rosdakarya

Isjoni. 2011. Pembelajaran Kooperatif Meningkatkan Kecerdasan Komunikasi Antar Peserta Didik. Yogyakarta: Pustaka Pelajar.

Kunandar. 2018. Langkah Mudah Penelitian Tindakan Kelas Sebagai Pengembangan Profesi Guru. Jakarta: Rajawali Pers.

Lie, Anita. 2008. Cooperatif Learning. Jakarta: Grasindo.

Poerwadarminta, W.J.S. 2003. Kamus Umum Bahasa Indonesia. Jakarta: Balai Pustaka

Sudjana.1999. StrategiPembelajaran. Bandung: Falah Production.

Tulus, Tu'u. 2004. Peran Disiplin pada Perilaku dan Prestasi Belajar. Jakarta:

Wahyudi. 2012. Matematika realistik dan implementasinya dalam proses pembelajaran. 